\title{
Constitutionalism and the Rule of Law
}

Noel B. Reynolds

Brigham Young University - Provo, nbr@byu.edu

Follow this and additional works at: https://scholarsarchive.byu.edu/facpub

Part of the Political Science Commons

\section{Original Publication Citation}

"Constitutionalism and the Rule of Law," in Constitutionalism and Rights, G. Bryner and N.

Reynolds, (eds.), Provo, Brigham Young University, 1987, 79-104.

\section{BYU ScholarsArchive Citation}

Reynolds, Noel B., "Constitutionalism and the Rule of Law" (1986). Faculty Publications. 1469.

https://scholarsarchive.byu.edu/facpub/1469

This Working Paper is brought to you for free and open access by BYU ScholarsArchive. It has been accepted for inclusion in Faculty Publications by an authorized administrator of BYU ScholarsArchive. For more information, please contact ellen_amatangelo@byu.edu. 


\title{
CONSTITUTIONALISM AND THE RULE OF LAW \\ $1986 / 87$ ? \\ Noel B. Reynolds
}

\begin{abstract}
:
Constitutionalism is the practical science of designing and balancing institutions of public power and authority so as to prevent monopolies of power or the emergence of tyranny. In spite of continuing attempts to ground constitutions in moralistic political theories, they are best understood as formalizations of citizenry agreements to manage their affairs under the rule of law following rules formulated by their legislatures and applied by their judges, all of which are to be selected through established procedures. The emergence of rule of law in primitive societies and in early modern European politics is noted, and the chief contributors to the twentieth century discussion are identified.
\end{abstract}

Key Words: constitutionalism, rule of law, natural law, primitive law, F. A. Hayek, Francis Wormuth, Ronald Dworkin, Charles McIlwain

The bicentennial of the Constitution of the United States of America invites our reflection on the extraordinary historical success of this document and its attendant institutions. In the history of mankind, it stands alone as the most successful of the sustained experiments in human freedom and self-government.

Such reflections may take on some urgency when we note the reduced level of basic constitutional wisdom which prevails among both the politicians, who are most directly responsible for maintaining the Constitution, and the political theorists, who provide our political culture with its self-understanding. It seems that the eighteenth century may have seen the high tide of such understanding in the western world. And the American Founders were without peer in their own day.

In this essay I will attempt to articulate the underlying principles which account for the success of the American constitutional experiment and indeed for similar freedoms that have been achieved in different degrees and for varying lengths of times in human polities throughout the world. The same analysis, by contrast, will serve to illuminate failures to achieve freedom 
elsewhere.

One indication of the decline in understanding of these matters over the last century occurs in the current edition of an authoritative reference work. The author announces somewhat disdainfully that "constitutionalism is the name given to the trust which men repose in the power of words engrossed on parchment to keep a government in order."1 Armed with such a narrow definition it is no wonder that the author is able to insist that "the rise of constitutionalism may be dated from 1776." ${ }^{2}$ From this most unpromising beginning the author goes on to develop a cynical account of the means by which clever lawyers and judges transform the doctrines of the Constitution over time to make of the document a useful instrument of social control. As if the Constitution had been intended as a repository or oracle for doctrines to settle all future questions of fundamental law! The appalling ignorance reflected in this authoritative source is only one indication of the widespread dearth of constitutionalist wisdom.

As difficult as some of our contemporaries seem to make the understanding of human freedom, we can find numerous historical examples of its achievement within the framework of rule of law and constitutional devices. This is important because it emphasizes the universality of the solutions which were perfected by the American founders.

\section{$\underline{\text { Primitive Societies }}$}

Rule of law through constitutional government is a recurring solution to an ageless problem in human societies, the problem of controlling the rulers. That there should be no rulers or government is a thought comprehensible only to a few theorists locked away in their ivory towers. That rulers need to be restrained has been the eventual discovery of every society. Constitutionalism is the science of such restraints. 
Because of their distance from modern society primitive cultures are often used to identify those elements of human societies which are universal. Studies of primitive political systems reveal constitutional arrangements which are designed to prevent the emergence of any single individual or group as a tyrant, while simultaneously providing for the necessary government to make orderly and beneficial decisions for communal action.

Our primitive brothers have access to one important control on their authorities that we have lost in modern secularized society--the requirement that they maintain the approval of the gods. The disapproval of the gods can be discovered by councils of priests consulting oracles or interpreting natural or social events. As one might expect, there are always very practical sanctions available to supplement the theological sanction of divine disapproval.

In most primitive societies political power is balanced and authority is distributed for the various kinds of community decisions which must be made. Councils are used in most cases to provide representative decisions. Elaborate rituals of rebellion are enacted annually in some monarchical societies to remind the king of his dependence on the support of the people. And without exception kings, chiefs, and councils are not authorized to change the laws and customs of the people. Furthermore, they are required to enforce those laws and customs and to obey them in the conduct of their own affairs. The common wisdom of primitive man seems to be that law or rules must also govern the rulers.

It might be thought that these primitive constitutional arrangements are ageless as they occur in different societies. This common western belief proves to be a myth as observers note the ongoing shifting of such arrangements in almost all such societies. Primitive peoples have never been immune to the dynamic forces of nature and society that impose continual change on 
their conditions of life. Wars, plagues, famines, and migrations disturb the important power balances that have been worked out at any given point in time requiring that new arrangements emerge.

Lucy Mair's studies of this process of change would support the conclusion that in times of constitutional failure primitive peoples naturally adapt previously non-political organizational elements of their societies to restructure their political system and regain constitutional balance. ${ }^{3}$ This is not to assert that such experimentation never misfires. But the politicization of social clubs or councils and the transformation of functions of existing political institutions goes on endlessly in the quest to balance power and authority within a continually changing society. The suggestion for us is that the constitutional problem is an endless one never to be resolved once and for all.

For example, the Iroquois suffered a major historical crisis when their ill-fated alliance with the English in the Revolutionary War forced them to leave the United States. Originally the Iroquois had no central government but only a ceremonial council of fifty chiefs. Because the English would only deal with the Iroquois through a single authoritative leader in the making of treaties, the Iroquois responded by conferring upon the council more and more specialized political functions and claiming for that council a monopoly of the representative right in dealings with the British. As time went on other problems emerged. The fur supply declined and the Iroquois resorted to war with distant Indian tribes to protect their control of the fur trade. To maintain these wars standing war chiefs were established. The British government first gave the Iroquois a Canadian endowment which embraced 12,000 square miles, but they were later forced onto a vastly smaller seventy square mile reservation. Again the council responded with the 
development of specialized offices. A welfare chief was appointed, then a forest warden, and so forth. ${ }^{4}$

Succession is a central constitutional problem, especially in the well defined kingship systems of many African tribes. Hilda Kuper found the constitutional arrangements of the Swazi of South Africa focused on a form of dual monarchy in which the king, or Great Lion, shared every prerogative with his mother. ${ }^{5}$ The queen mother, or Lady Elephant, had her own courts, counselors, and troops, as well as some authority over the king. The queen mother actually functioned as a court of appeal and would be replaced by her own sister or daughter should she die. In addition to the balance of the dual monarchy there were permanent councils composed of the heads of the various lineages that were also involved in decision making with the king. Rituals of rebellion have been observed among certain African tribes and the Natchez Indians of Louisiana. Max Gluckman reports that the king of the Zulu was required to make an annual wandering through the villages of his kingdom naked and without arms or supplies. ${ }^{6}$ As he appeared in each village he would be persecuted and even threatened with spears and abused with language ordinarily reserved for the most vile members of this society. This ritual reminds a king of the precariousness of his position and that a real rebellion may lead both to his death and his replacement. If in fact he returns safely from the tour, he resumes his kingly regalia, receives the praise of his people, and is reinstated in his position. But he has been sharply warned that he must always remember to seek the welfare of his people.Classical

\section{Constitutionalism}

The failure to see the antiquity of constitutionalism is directly related to the failure to see this institutional balancing of the social decision making process as its essence. Constitutional 
thought, in this sense, was explicitly developed among the ancient Greeks and Romans, as evidenced not only in the writings of Plato, Aristotle, Polybius, and others, but also in political institutions over a period of many centuries. It seems clear that Plato saw that a primary function of government was to protect and maintain the law of the people. ${ }^{7}$ He furthermore explicitly discussed the various institutional designs that might be used to achieve this, namely monarchy, aristocracy, and democracy. His almost casual, yet sophisticated, treatment of these concepts betrays his assumption that his contemporary audience understood these matters completely and that little detailed explanation was necessary. As Plato went on to name the corrupted forms of his three constitutional regimes, he clearly saw the source of corruption in their failure to maintain the rule of law as they fell into tyrannical practices. Plato was not an optimist; he seemed to believe that each of the good regimes bore within itself the seeds of its own destruction--a view of all worldly constitutions which Bentham echoed in the nineteenth century, asserting that only the constitution of the Anglo-American United States "affords a reasonable promise of everlasting endurance." ${ }^{8}$

Because Plato wrote in dialogue form, his views in these matters are not as apparent as those of his student, Aristotle, who used the philosophical treatise. To Plato's notion of a general cycling through the different regimes and their corruptions, Aristotle added the idea of mixed government wherein the democratic, aristocratic, and monarchical elements of the state could be mixed into one regime which could have the potential for sustained balance of constitutional power. The Aristotelian idea of mixed government formed the basis for classical constitutional theory in conjunction with the commitment to the principle of rule of law. ${ }^{9}$ The idea was revived and revitalized in modern Europe, particularly England, and even served as a guiding ideal to the 
American founding fathers who struggled with the problem of institutional balancing in a society which did not have an aristocracy or a monarch.

Plato and Aristotle were writing within a tradition that had long treasured law and the principle of rule of law. The early Greeks credited their laws to their divine ancestors and therefore gave no earthly mortal a right to change those laws. The ancient poet, Pindar, expressed that Greek view--"The law is king of all." ${ }^{10}$ In the early history of the Athenian constitution the commitment to law was a constant. Over time a wide variety of political institutions emerged to secure and maintain that law including monarchy, aristocracy, and democracy. Even though none of these had authority to change the ancient law it was under constant revision through one or another process of interpretation. But as late as the fifth century the ancient Athenians maintained constitutional watch-dog bodies that could punish a magistrate for acting beyond his legal authority.

We know more about the law of ancient Rome, but find in it the same type of constitutional commitments used by the Greeks. Private law was the original source for all Roman law. The public law, as it developed, was conceived as a form of generalized private contract. Government structures were developed over time explicitly to maintain and enforce the law. This pattern is strikingly analogous to that of English common law centuries later. But as time went on and the Romans enjoyed international success they had to adapt their law to imperial circumstances. They adopted new fictions which allowed the emperor to announce the will of the people, the recognized ultimate basis of all Roman law.

The later reputation of Roman absolutism unjustly descends from this Justinian formulation. But the true Roman doctrine which was reasserted in the Middle Ages was that the 
populace is the source of all law and that any public law and especially any tax must be based on consent. One of the great twentieth century scholars of constitutionalism, Charles H. Mcllwain, concluded that "whatever our modern laws may be, Rome is the source of our jurisprudence, and whatever our form of government, Greece has furnished us the main outlines of our political science. ${ }^{11}$

$\underline{\text { Medieval Constitutionalism }}$

The constitutional struggles of the Middle Ages were carried on at two different but interrelated levels. On the international level the popes struggled with the emperors and the kings while on the national level kings struggled with their own people. The story is far too long and too complicated to be even summarized here, beyond noting that with respect to the papal struggles the kings eventually won the right of approval for the appointment of bishops as well as the right to rule over the bishops within their territory. ${ }^{12}$ Furthermore, as a concession to the secular authorities, the selection of popes was finally regularized by a rule requiring the agreement of two thirds of all the cardinals. The papal argument that all legitimate political authority is derived from and subject to the pope and the view that all material goods in the world are ultimately owned by the pope so that all earthly rulers are stewards to the pope--as advanced in its latest form in 1301 by Giles of Rome--were ultimately overthrown.

John of Paris produced the most important constitutional analysis of the age. He responded to this logical and perverse extreme, arguing that the pope is only a steward for the Christian community and its properties. Following Aquinas, he saw in civil government intrinsic dignity without any claim to ecclesiastical derivations, and concluded, therefore, in favor of a meaningful separation of church and state as a matter of constitutional arrangement. John 
justified popes in their spiritual censuring of kings and encouraged the deposition of wicked monarchs. But kings, he thought, could assist the cardinals in deposing an evil pope by force of arms! John was successful in bringing to the constitutional theory of the middle ages a view which was consonant with developments within the individual kingdoms. The best government in both church and state is representative and responsible to the people and protective of their laws.

The classic doctrine of a mixed state died out as a political institution during the Middle Ages except in the Italian republics. Yet the idea was kept very much alive in literature as medieval writers tended to recall the successes of the Roman Republic. Aquinas argued that mixed government was the form of rule provided by God for the Israelites. John of Paris continued the defense of mixed government in his constitutional writings. The anti-papal writers in the Conciliar controversy even went so far as to argue that the Church should develop a form of mixed government. And finally, the Renaissance writers such as Machiavelli and Erasmus succeeded in making the notion of a mixed state commonplace, even though the medieval pattern was kingship in almost every country.

The dualistic nature of medieval kingship probably resulted from the military organization of the Teutonic tribes in the early Middle Ages. The kings, as military leaders, held personal rule; and the business of government devolved upon the king as part of his household responsibilities. Every subject was personally tied to his king with a bond of allegiance.

As the story is similar throughout Europe, the English experience can be representative. Before the advent of feudalism, vast areas of life in England were organized without any reference to the king. Land was owned outright by allodial tenure. The kings did not even enjoy 
the right of taxation until the tenth century. And folk courts carried the responsibility for law enforcement serving almost like private arbitration boards or tribunals. Clearly the political function of the king was extremely limited and the law of the people was the primary source of social control.

The early feudal kings attempted to redefine their political relationship to their subjects in terms of a divided land title and to convert kingship into a legal office. The late medieval struggles between the kings and the barons resulted in kings retaining position as a personal rulers entitled to personal allegiance--but with limited power. Property retained its traditional autonomy so that taxation never became a royal right, but took the form of a voluntary grant given through parliament to the king. By virtue of his office, the king assumed responsibility for the administration of the law, but his judges could only enforce the existing rules and analogies of land law. They could not carry out new conflicting orders of the king.

Scholars have attempted a variety of analyses to explain this form of limited monarchy that occurred in these middle centuries. The English jurist, John Fortescue, saw this as a combination of "royal and constitutional rule," or in other words, a monarchy in which the king ruled and made laws only with the assent of his subjects. Fortescue used this constitutional feature to distinguish between the royal rule of France and the limited monarchy of England.

One modern scholar of medieval political theory treats the same idea under the rubric of "double majesty."13 Gierke believed the various theories of double majesty emerged as means of imposing limits on kings. But in the Middle Ages, two of these were most prominent--both deriving from Roman sources. It was characteristic of medieval writers to assert natural or universal law as a limitation on the prince. This ancient Stoic view had some influence, 
especially with philosophers at different points in time. But the more compelling legal view was the notion that law and the right to rule derive from the people in accordance with the ancient principles of Roman law.

McIlwain prefers to use Bracton's medieval distinction between qubernaculum the king's unlimited sphere of action, and jurisdictio, that sphere within which the king is bound by law, whether it be natural law or custom. ${ }^{14}$ The Achilles' heel of limited government in England was the absence of an institutional device that could restrain the king. What could the barons do when the king exceeded the understood limits? History shows that rebellion was their only real alternative. Their confrontation of John at Runnymede--resulting in the Magna Carta--was only one of many such occasions in this general period.

McIlwain explains the breakdown of the medieval constitution as the outcome of a long struggle between monarchs and subjects to extend their respective spheres of government at the expense of the other. The tide of royal despotism crested in the sixteenth century with the royal promotion of doctrines of unlimited obedience to kings and of divine right of kings. This trend came to a head in the early seventeenth century with James I's assertion that the liberties of the people were not a matter of right, but of royal grant.

McIlwain does not believe that constitutional limitation could have survived had it not been for several unique characteristics of English political and legal life. The incredible toughness of English common law proved adequate to resist the royal attack. Determined English judges in the late sixteenth century refused to obey explicit orders from the monarch on the ground that they were of no force being "against the law of the land," and got away with it until the Stuarts gained control. The religious schisms of the times led dissenters, most notably 
Puritans, to revive old hostilities toward tyranny, bringing the defenders of law into an alliance with the schismatics against the expanding prerogative of the crown.

Although Parliament had not yet come into existence as an independent institution, defenders of law such as Coke and Wentworth asserted as early as 1621 that Parliament was the voice of the people--the essential premise of government on the Roman legal model. As the courts began to cave in to the Stuart monarchs, giving them discretion to make gubernaculum supreme over jurisdictio, double majesty was abandoned and revolution appeared to be the only course left open to the parliamentarians. How else could they deal with the star chamber denials of due process and the extra-parliamentary tax assessments?

\section{$\underline{\text { Modern Constitutionalism }}$}

Francis Wormuth has given us an outstanding analysis of the twenty years of constitutional speculation spawned by the English civil wars. ${ }^{15}$ The Cromwellian years were characterized by experimentation and discussion of ideas including popular sovereignty, written constitutions, constitutional limitations, separation of powers, checks and balances, and bicameralism, among many other principles and institutional devices. Though written at this early date, James Harrington's Oceana served as a major inspiration for the American founders, and notably John Adams. Many of the constitutional ideas which later came to fruition in the American experience first had a serious hearing in England at this time. But they were largely premature and unsuccessful in their own time.

With the demise of the Commonwealth in 1659 monarchy returned to England. Republican thinking was not eliminated, but was preserved more in the principles than in the institutions of politics. The Glorious Revolution formalized this arrangement in 1688 bringing to 
an end once and for all the claims of English monarchs to any absolute right of rule. Unfortunately, there was not sufficient foresight to provide against Parliament's filling the vacuum.

There is little doubt that eighteenth century America was the setting for the historical high point of constitutionalism. Never before or probably since have such broad segments of a single population understood and valued the essential principles of the rule of law and the notion that the arrangement of political institutions can best serve as the fundamental device for protecting the law from tyrannical governors.

It is a commentary on our own times that we so frequently misrepresent the intellectual views of the men who produced the constitution of 1787. A few years ago I had the opportunity of conversing at some length with a noted English historian and political theorist who made some comments on the American revolution and constitution. But his account sounded more like a description of the French experience after 1789. With some gentle probing I established to my dismay that my friend actually believed that the American Constitution features abstract announcements of natural law principles, and that the basic rationale used by the Americans for declaring their independence was an appeal to nature and political theory. He was astonished and even somewhat incredulous as I tried to point out that at no point does the American constitution advance any principle of natural law or political theory, that it only specifies the respective functions of and limitations on the various governmental agencies which it creates, and that the revolution itself was quite deliberately justified in terms of the violation of the colonists' legal rights as Englishmen by the Crown in abuse of its lawful authority. The opening sentence of the Declaration announcing that all men are created equal cannot outweigh all the rest. It is certainly 
true that the American founders did hold ideologies which included various principles of natural and divine law. But their constitutional documents do not mention these, and certainly do not rest on them directly as did the French parallels.

The debates over the American Constitution provide us with some of the best discussions of the basic rationale for constitutionalist theory, and James Madison provided the clearest and most widely used examples of that rationale. ${ }^{16}$ Scholars are at least partially correct in tracing the intellectual inspiration of American political thinkers to such writers as Locke, Montesquieu, and the English radicals. But they are only now coming to realize the extent to which the Scottish philosophers, and particularly David Hume, produced the theoretical insights which guided the founders. The Constitution is not a Lockean contract. Rather it is an attempt, in the American context, to achieve the kind of institutional balancing and protection of law so esteemed by Hume in his History of England and Political Essays. ${ }^{17}$ One author has found throughout Madison's and Hamilton's writings repeated references and borrowings from Hume, even beyond the point where his arguments were relevant to the American context. ${ }^{18}$

A decade of experience with themselves and the Articles of Confederation had disabused these American luminaries of any unwarranted optimism about their own abilities to stand aloof from self-interest that might have been generated during their remarkable revolution. As they drew themselves reluctantly back into the folds of Hume's philosophy, Madison's lament that men are not angels became again an American commonplace. That basic assumption about the nature of man or the expectations that we might have for human behavior lies at the very root of constitutionalist thought. For if men will not abuse power and are capable of error free decision making, there is no need of a constitution. Madison certainly did not claim that every man would 
necessarily abuse power when given the opportunity. But, from a statistical point of view, he would say that any institution which permitted or rewarded the abuse of power would eventually degenerate into tyranny.

\section{$\underline{\text { Political Theory and Constitutionalism }}$}

This assumption about man shapes constitutionalist thought at several levels. Whether articulated or not it is the insight that compels all human societies to recognize that laws are essential for human interaction. Not only are men generally incapable of coming to a full agreement on general moral principles of conduct, but they are even less capable of consistently adhering to those principles once established. And so, law becomes necessary to make life in society tenable. Law becomes a substitute for that moral and intellectual ideal which the human imagination continually generates anew. Given the nature of man, law is the highest form of social organization to which we can in fact achieve.

At a second level, law requires enforcement and enforcement agencies. Governments with coercive power create a second level on which human selfishness and power lust can act out their course. Constitutionalist thinkers have recognized the necessity of institutional constraints on public authorities to prevent them from corrupting the rule of law. Legal rules limiting the officials are of no value if there are no institutional procedures and balancing arrangements that check them from corrupting the rules through arbitrary and self-interested interpretations.

For a society to maintain its laws over time, it must agree in advance on the procedures and officials by which future disputes under the law will be decided. The community must also determine how those officials will be selected at any point in time. These are constitutional choices. But the science of constitutionalism focuses most importantly on a third choice--the 
arrangements for balancing governmental institutions to prevent them from degenerating into perverse instruments for advancing the private fortunes of government officials or a privileged class.

Francis Wormuth was one of the first to help contemporary scholars see that the essence of constitutionalism is this concern with "auxiliary precautions" as they were called by James Madison or "contrivances which not only describe but confine government, at least in its everyday activities. ${ }^{19}$ F. A. Hayek eventually came very close to this when he defined constitutional law as a superstructure erected to secure the maintenance of the law, rather than the source of all other law. ${ }^{20}$ McIlwain was less sensitive to the problem of institutional devices in his definition of constitutionalism as "the limitation of government by law," although his studies of the English constitution clearly indicate that he saw the weakness of the English constitution in its failure to develop institutions which could balance the governing authority of the king over a period of four centuries. ${ }^{21}$ Much less appreciation for this definition is evident in the writings of Tom Paine, for example, who saw constitutions as "antecedent to a government" and believed that governments were "only a creature of a constitution." 22

Because constitutions set the conditions for law making, it is commonly assumed that laws are somehow derivative from and subsequent to constitutions. But the opposite view is more easily defended from the historical record which shows that law usually precedes a constitution. It is specifically to preserve the law and the regular administration of law that constitutions have been designed. The whole point of a constitution is to protect the law of the people which seems to be threatened by their rulers. The examples of the endless series of medieval charters such as Magna Carta comes to mind where the people would rise up--not to 
overthrow the king--but to compel him to promise to maintain and respect the law or "the liberties of the people." History credits those wise conquerors who have preserved the law of the conquered nations. This was the wisdom of the Romans and the Norman invaders of Britain.

The least comprehending definition of constitutionalism is one that sees it as an exercise of moralistic political theory committed to the task of discovering the correct fundamental principles for reconciling liberty and equality. This latter moralistic enterprise has virtually consumed the attention of our political and legal philosophers today. Few of these are concerned to identify practical institutional devices that would prevent the kinds of inequities or violations of right on which they focus. Rather their concern is to find some philosophical principle which defines just law from a moral point of view.

I do not question that this is an interesting and worthwhile enterprise. But to see its connection with reality, we must remember that legal and constitutional thought have to start from a recognition that people do not always act on the basis of disinterested moral principle. Our experience teaches us that they act from self-interest and that before morality can become a guiding feature of social life, self-interest must be controlled in practical ways. We will not pave the way to Utopia by finally discovering the true philosophical account of justice. Rather, Utopia could only be possible in a world where men had ceased to pursue self-interest at the expense of others, where they had ceased to be men, and had become angels.

Much of the contemporary failure to recognize institutional safeguards as the true basis of our freedoms stems from our uncritical acceptance of the claims of the moralistic enterprise. One European historian praises the French Declaration of the Rights of Man of 1789 specifically because it "is concerned with the rights of man, not the rights of the citizen." In other words it 
focuses on "universal human rights" which focus will in time produce "the new man" and "the new citizen." 23

De Ruggiero gives us here a marvelous example of the naivete of the extreme liberal view that once people hear the moral truth, they will naturally conform their lives and social institutions to it. Where would the Americans be today if Madison had believed that?

It is not likely that we could find in the eighteenth century a document which reflects a stronger commitment to the principles of freedom under law than does the French Declaration of the Rights of Man. Yet the French Revolution failed to produce that freedom. My argument is that a significant part of the reason for that failure is that the announcement of true political principles in a constitution accomplishes nothing and may be counterproductive. For if the government is not properly designed and balanced to prevent the emergence of a tyrant, the principles will be interpreted by officials who are free to use the power of government to pursue their own ends, and the principles will be as nothing. James Madison repeatedly referred to constitutional articulations of general constitutional principles as "mere parchment barriers."24 Certainly the Americans believed in most of the principles announced so confidently to the world by the French. But they mention none of them in their own Constitution. Upon reflection we can see in their work profound evidence of the genius and effectiveness of centuries of constitutional experience in England and colonial America. The Americans set their hands directly to the problem of designing an internal balance and complication of decision making processes that would prevent the concentration of power in the hands of a single faction.

There is among English speaking populations a simple rule for dividing a cake which epitomizes their constitutional wisdom. The rule does not say the cake must be divided evenly or 
that it should be divided on some other principle of fairness. The rule simply says, "He who cuts the cake must choose his piece last." This rule is no less concerned with equality and fairness than is the liberal French rhetoric. But without mentioning such principles it brings them far more effectively into reality.

No legal theorist has attracted more attention in the last twenty years than has Ronald Dworkin. $^{25}$ Yet Dworkin has publicly urged the Supreme Court and judges generally to see their responsibility to reach behind the law to the unquestionably true principle of equality to guide them in the resolution of difficult cases. ${ }^{26}$ This dangerous course can only serve to provide rationalizations for those that would promote their own political and moral views through law and in the process create legal confusion and destroy our ability to predict the legal implications of our actions, as the rule of law requires.

And so I emphasize my conclusion that natural law, or any moralistic theory of constitutionalism, fails radically to see that the root of law is not moral truth. It is rather convention, agreement, which may or may not be derived from the popular morality, but it is emphatically not natural law. This may be a pessimistic view; but it is nonetheless true that it is the lot of men in communities to live by law as a substitute for moral truth.

To live by moral truth as a community seems beyond us. And as every primitive society and historical culture that has achieved freedom under a constitution has discovered, that freedom has come through institutional design and balance and not through philosophical or ethical discoveries.

The kind of attack that I have made on constitutional articulations of abstract rights or metalegal principles is easily misunderstood and may need clarification. In the first place I 
should stipulate that it is not an attack on the idea or the existence of rights. Rather, most constitutionalists do assume that people have rights. Furthermore, I strongly endorse moral philosophy as an important enterprise in helping us see the implications of different theories of rights. I believe that pro rights propaganda efforts are a very positive contribution to political society and provide necessary encouragement for the maintenance and protection of those rights through constitutional devices.

However, on the basis of practical considerations we must reject the abstract rights approach to constitutionalism. The constitutional problem is the practical problem of preventing public authorities from corrupting the law. It is the law which articulates our liberties or rights. Abstract statements of rights or constitutional principle are worthless in constitutions. My argument is based on the observation that only institutional balancing has any real effect. Furthermore, I would argue on the negative side that statements of abstract rights are potentially very mischievous, this because an unchecked authority can interpret such general statements of right to suit its own interest and then exploit the sweeping substantive language. The liberals who do not believe this should remind themselves of the substantive due process reasoning developed by conservative American judges near the end of the last century.

A further practical reason for avoiding the abstract rights approach is that it requires theoretical agreement on the content and justification of the rights protected for adoption. Political agreements on policies to be pursued or institutional devices to be used in decision making can be reached between parties which might never be able to reach agreement on their reasons or justifications for those policies, or their theories about rights. A moralistic approach to constitutions which seeks to preserve rights by incorporating abstract or principled 
articulations thereof in constitutional documents has far lower prospects for developing adequate popular support for any single theory to be adopted. We can agree much more quickly on institutional and policy statements than on theoretical ones.

My argument therefore is not against the enterprise of moralistic, political philosophy. This has an essential and positive function. The error of many moralistic philosophers lies in their uncritical jump from abstract moral thought to constitutional theorizing. I do not necessarily disagree with their moral views. But I believe they are too often naive about constitutions. They do not exhibit adequate understanding of constitutionalism.

The most frequent mistake of the moralistic philosophers in making that jump is the assumption of benevolence which sneaks in unnoticed. Rawls, for example, acknowledges that there will be strains placed on the contract from the poor, but he does not anticipate the strains which will come from the better off, who are being taxed to help the poor. The assumption of benevolence is not recognized or discussed. And this is characteristic of the moralistic approaches to constitutions, which overlook the problem of human nature at its crucial point of application.

The constitutional problem is a permanent feature of human society which can never, even in principle, be finally solved once and for all. There will never be one perfect institutional design which will solve the problem of tyranny forever. As described above, human nature is such that inventive men seeking their own interests will always find ways to work new angles and corrupt or undermine institutional arrangements which may have functioned successfully in the past. Natural or external events can also dramatically affect the artificial balances of a constitution as migrations bring cultural mixing, or as famines, wars, and plagues change the 
configuration of populations and the conditions of life. Economic growth has a similar effect. All of these can have constitutional consequences. Because constitutionalism addresses a permanent problem, it is essential that we pay attention to it in a systematic way and preserve the wisdom that the centuries have brought us for dealing with these changes.

Finally, all constitutionalist thought assumes that law is the appropriate response to the problems of human nature and community. The rule of law creates the context of freedom whereby individual men may pursue moral perfection as they understand it without inflicting their own views of perfection on others. Law is the means by which we prevent arbitrary or willful interventions in the lives of individuals by those who must necessarily be chosen to enforce the rules of the game.

$\underline{\text { Public Virtue and Constitutionalism }}$

It could reasonably be argued that the beliefs of ordinary people influence the fortunes of constitutional government more than the theories of philosophers. A universal feature of successful constitutional regimes has been a cultural commitment to rule of law. For a constitution to succeed the community belief systems must support its aims. There must be a commitment to the law and rule of law. "Constitutionalism means that all power rests on the understanding that it will be exercised according to commonly accepted principles." 27

It is the absence of that cultural commitment among the people themselves which explains the ongoing failure of Latin American attempts to imitate the American constitution. In too many countries, the oppressive culture of the strong man is ingrained in the people. Even when the peasants successfully revolt and come to power, they turn the tables and become themselves oppressors, not only of their vanquished predecessors but of their own class, in a 
cycle which has played itself out now for two centuries. Solzhenitsyn attributes the amazingly successful imposition of strong communist rule on a compliant Russian citizenry to a similar cultural defect. ${ }^{28}$

The eighteenth century Americans, on the contrary, had the benefit of cultural expectations built up through centuries of English commitment to rule of law and constitutionalism. A century of benign neglect had allowed them to develop de facto institutions for self-government as well as inflated views of what their legal rights as Englishmen might be. When the central government undertook to restore firm control over the colonies after 1760, it was too late. And when the newly independent Americans undertook to form a new government, they remembered that good government requires some private sacrifices. The Americans of the late eighteenth century enjoyed a unique heritage in that they understood the dependence of freedom upon rule of law and constitutional government, while they were also willing to make some personal sacrifices to establish and maintain a republican form of government. Most of their eighteenth and nineteenth century imitators were not so fortunate.

Analysis of Rule of Law

At mid-century it might well have seemed that serious interest in the idea of rule of law was almost dead among intellectuals. The concept had fallen into disuse, and the understanding of that concept was certainly in decline among legal and political philosophers. The ideology of democracy and equality had taken over center stage in the discussions of academicians.

However, in 1960 F. A. Hayek published an analysis of rule of law that went beyond anything developed by earlier thinkers. ${ }^{29}$ Since Hayek's book other notable scholars have made further statements on the subject. In 1964 Lon Fuller identified certain principles, or norms, which 
constitute an "inner morality of law"--principles including generality, publicity, clarity, coherence, and possibility. ${ }^{30}$ In 1966 J. R. Lucas published an important elaboration of the analysis of rule of law that was also partially derived from Hayek's discussion. ${ }^{31}$ Finally in 1975 John Rawls used the notion to bolster his process theory of justice, even though he treats the subject from a moralistic point of view. ${ }^{32}$ In his 1980 book, John Finnis used the idea of law to try to bridge the classic gap between accounts of natural law and natural rights. ${ }^{33}$ And in 1983 Michael Oakeshott published the essay which brings formal discussion of the issues to its highest level. ${ }^{34}$ But most political and legal philosophers continue to ignore this issue and do not put much emphasis on an analysis of the concept.

Because the notion of rule of law is crucial for an understanding of constitutionalism, it is essential that we develop an adequate account of the concept. On the face of it there are discrepancies of serious magnitude between the various accounts mentioned above and within each individual account. Even Hayek's ground breaking account fails to make certain elementary and essential distinctions. The question then seems to be, how can we lay out the logical elements of the concept to provide some coherent order for its attendant principles, assumptions, and implications? The following paragraphs are only a summary of preliminary points that should be considered before taking on this larger creative project.

Any discussion of rule of law begins with the assumption that liberty is desirable, that there is a need to protect a sphere of individual freedom. That may be regarded as a moral value, but it may also be regarded as a simple preference. People want to have freedom for themselves. As we begin to answer the question of how that freedom might be obtained, we need to make a further assumption about the nature of the world in which we live, particularly the nature of man 
himself. What kind of a creature is it that we want to make free? This is not a metaphysical question. Rather it is an empirical inquiry which asks what tendencies should we expect to observe in human behavior.

There are several answers that might be given to this. We might, for example, assume that men are naturally cooperative and respectful of the rights of one another, in which case we would then conclude that some form of anarchy or possibly a moral utopia of some sort might be possible to achieve. If we assume with the more conservative tradition in western thought, that men will generally pursue their own self interest--even, in many cases, at the expense of innocent third parties--and that we cannot expect men to either know or discover the truth, then we will conclude that a society of law offers the best practical alternative political regime. On that view, laws would be the practical substitute for moral principles in a regime in which it is recognized that general adherence to true moral principles is not a rational expectation.

We can define the society of law, or the rule of law, as an arrangement in which the individual is able to plan his own life by adhering to rules by which he will avoid all penalties enforced by law. Such a definition entails several assumptions.

1. It assumes generality, that rules lay down general standards of conduct for all citizens equally.

2. It assumes that the rules will be stated with sufficient clarity, that there is little or no question what forms of behavior are permitted or prohibited by the rule.

3. It assumes that the rules are coherent, that is, that there is an established hierarchy to determine which rules govern in cases of conflict and that there are not conflicts in the rules governing the same situations. 
4. It assumes that the rules are public, that they are available and known to the citizens.

5. It assumes that the rules are possible, that they can be followed, that they do not require impossible or even unreasonable behavior.

6. It assumes that the rules are prospective, that they refer to their own future and not to the past.

7. It assumes that the rules are backed by authoritative enforcement, that there is governmental structure responsible for determining cases of conflict under the rules.

Once we have identified these necessary characteristics of the rules themselves, we can inquire into the characteristics of the institutions which might be expected to maintain and enforce this kind of rules without interjections of arbitrary will. Recognizing the natural institutional tendency toward tyranny inherent in our assumption about human nature, we could recommend that the government have the following general characteristics:

1. It should be based on a separation of powers. The power to make laws must be separated institutionally from the power to enforce the laws. This is fundamentally a restriction that legislators may not enforce their own rules.

2. Every individual must have equal legal rights as he confronts the enforcement of law.

3. The government must be subject to the periodic approval of the people which it rules. The point is to prevent tyranny through responsible government. Consent should be achieved in two ways. There is assumed at a most fundamental level a 
constitutional agreement. The second level is the consent to officials who will decide on the laws and the enforcement of law. Republicanism was a modern theory of consent.

4. An independent judiciary seems to be necessary in principle to protect rule of law from potentially tyrannical governments.

5. Hayek has pointed out that there must always be provision for exceptions to any of the above principles or to laws that may be valid in a given polity. But in principle, such exceptions must be both justified and compensated at the time.

The principles listed above and others not mentioned seem to include rules which are enjoined on legislatures and judges. But the rules are not self-enforcing. There needs to be institutional devices that will carry the rules into effect. The actual devices used in any particular political system might vary widely. Some devices will be more successful than others. But the rules themselves will often appear ambiguous in concrete situations. It is therefore necessary to institute procedural standards as the only effective way of enforcing the guidelines. As one examines the provisions of the American constitution one is struck by the fact that none of the principles of rule of law are announced or explained, or even set forth. Rather the document only lists the procedures and the devices by which the founders hoped to achieve the effect of the principles identified here.

Many of these principles are implemented at least partially through specific prohibitions on the powers of government or specific institutional devices. For example, the principle of generality is supported by the prohibition on bills of attainder; the principle of prospectivity is implemented by the prohibition on ex post facto laws. Some of Fuller's principles such as clarity, 
coherence, and possibility, tend to be implemented primarily through judicial rules of interpretation. We find laws which are unconstitutionally vague to be unacceptable in our system. We have a supremacy clause which gives some hierarchy and coherence in the legal system as a means of supplementing judicial rules of interpretation. Publicity is protected by the prohibitions on the infringement of free press and speech as well as the requirement that legislatures publish their proceedings and that legislatures and courts deliberate in the public view.

The principle of separation of powers is implemented with a large collection of constitutional devices. Most notable among these are the division of the operation of government into three branches and the further division of the legislative branch into two parts. Institutions such as judicial review and the various checks and balances protect the independence and integrity of the three branches, thus indirectly supporting the notion of separation of powers. Madison called this the doctrine of partial agency.

Formal equality is implemented in specific provisions prohibiting creation of royalty and nobility as well as rules guaranteeing equal legal rights to citizens of every state. The principle of consent is primarily implemented through the mechanisms of representative government, as well as the provisions for the ratification of the constitution and subsequent amendments. An independent judiciary is provided through prohibitions on juggling either the tenure or the salaries of judges during their service. Protection from exceptions occurs in the eminent domain clause.

\section{$\underline{\text { Summary }}$}

In this essay I have briefly looked at the political institutions of a wide variety of societies 
to demonstrate the universality of both the political problem (the tendency to tyranny) and the best human solution (rule of law under the protection of constitutional arrangements.) As an antidote to the decline in our understanding and appreciation for the idea of rule of law I have argued that constitutions should be seen as collections of institutional devices or arrangements designed to prevent the emergence of tyrants in the process of settling private or public disputes, and not as pronouncements of general principles of political morality.

Secondly, I have insisted that not every collection of institutional devices will constitute an adequate constitution. To succeed a constitution must preserve and promote the rule of law, the point of which is to make official response to private action as predictable and avoidable as possible for the citizen. No amount of moralizing or breast-beating will compensate for a well conceived system that provides practical barriers to factional takeover of the powers of the state. And inappropriate reliance on moral principle as law can give factional interests the weapon they need to implement their despotic programs.

Finally, I have recognized that the possibility that any particular polity will be able to achieve and maintain a system of law depends as well on the extent to which the political culture includes a commitment to law as a means of creating that individual sphere of freedom to pursue the good. Rule of law, by refusing to nationalize moral truth, makes its universal pursuit at the individual and voluntary association level a concrete possibility. 
NOTES

1. Walter H. Hamilton, "Constitutionalism," Encyclopedia of the Social Sciences, vol. 4 (London: Macmillan, 1930-1935), 255.

2. Ibid.

3. Lucy Mair, Primitive Government (Harmondsworth: Pelican, 1962).

4. I am grateful to Merlin G. Myers for sharing these observations based on his dissertation research.

5. Hilda Kuper, "The Swazi: A South African Kingdom," George and Louise Spindler (eds.), Case Studies in Cultural Anthropology (New York: Holt, Rhinehart and Winston, 1963).

6. Max Gluckman, Rituals of Rebellion in South-East Africa (Manchester: Manchester University Press, 1954).

7. See Noel B. Reynolds, "Plato's Defense of Rule of Law," in the forthcoming proceedings of the World Congress for the Philosophy of Law and Social Philosophy, Athens, 1985, where I defend this controversial claim about Plato. That Plato understood and defended the idea of rule of law as an appropriate ideal for human societies is clear in all the epistles and in almost all of the dialogues. The exception is Republic, which gives an ironic defense of philosophical totalitarianism, which many commentators have mistakenly taken at face value.

8. This comment was originally published in Jeremy Bentham, "Leading Principles of a Constitutional Code for any State," The Pamphleteer, No. 44 (London, 1823.), II, 7 n. It can now be found in John Bowring (ed.), The Works of Jeremy Bentham, vol. 2 (Edinburgh: William Tait, 1843), 273.

9. See the excellent and very brief discussion in Harvey C. Mansfield, Jr., "Constitutionalism and the Rule of Law," Harvard Journal of Law and Public Policy 8 (1985): 323-326.

10. Pindar, De Pindar: The Odes of Pindar, Including the Principal Fragments, Intro. and trans. by Sir John Sandys, edited by T. E. Page, Loeb Classical Library (London: William Heineman, Ltd., 1946), 169. The Greek text reads, "nomos ho panton basileus."

11. Charles H. Mcllwain, The Growth of Political Thought in the West (London: Macmillan, 1932), 3. 
12. See Brian Tierney, The Crisis of Church and State (Englewood Cliffs: Prentice-Hall, 1964).

13. Otto Gierke, Political Theories of the Middle Age, trans. F. W. Maitland (Cambridge: Cambridge University Press, 1900).

14. Charles H. McIlwain, Constitutionalism, Ancient and Modern, rev. ed. (Ithaca: Cornell UP, 1947), 77-79.

15. Francis D. Wormuth, The Origins of Modern Constitutionalism (New York: Harper, 1949).

16. James Madison, The Federalist Papers.

17. Frederick G. Whelan, Order and Artifice in Hume's Political Philosophy (Princeton: Princeton University Press, 1985), 348-373 is an excellent new study which thoroughly vindicates the eighteenth century Americans' reading of Hume.

18. Garry Wills, Explaining America (New York: Doubleday, 1981).

19. Wormuth, The Origins of Modern Constitutionalism, 3.

20. F. A. Hayek, Law, Legislation, and Liberty (Chicago: University of Chicago Press, 1976).

21. McIlwain, Constitutionalism, 21.

22. Ibid., 14.

23. Guido de Ruggiero, History of European Liberalism, trans. R. G. Collingwood (Oxford: Oxford University Press, 1927).

24. See The Federalist Papers, Nos. 47-51.

25. Ronald M. Dworkin, Taking Rights Seriously (London: Duckworth, 1977).

26. Ronald M. Dworkin, Political Judges and the Rule of Law (London: The British Academy, 1980), 282.

27. F. A. Hayek, The Constitution of Liberty (Chicago: University of Chicago Press, 1960), 181.

28. See especially the opening chapters of Alexander Solzhenitsyn, The Gulag Archipelago 3, trans. H. T. Willetts (New York: Harper and Row, 1978).

29. Hayek, The Constitution of Liberty, 205-219. 
30. Lon L. Fuller, The Morality of Law, rev. ed. (1969; New Haven: Yale University Press, 1964), 33-94.

31. J. R. Lucas, The Principles of Politics (Oxford: Clarendon Press, 1966), 106-162.

32. John Rawls, A Theory of Justice (Cambridge: Harvard University Press, 1975), 235-243.

33. John Finnis, Natural Law and Natural Rights (Oxford: Clarendon Press, 1980), 266-290.

34. Michael Oakeshott, "The Rule of Law," On History (Oxford: Basil Blackwell, 1983), 119-164. 